\title{
Phytopathology
}

PERSPECTIVES

\section{Money Matters: Fueling Rapid Recent Insight Into Xylella fastidiosa-An Important and Expanding Global Pathogen}

\begin{abstract}
Steven Lindow ${ }^{\dagger}$
Department of Plant and Microbial Biology, University of California, Berkeley, CA 94720.

Accepted for publication 3 September 2018.

ABSTRACT

Xylella fastidiosa has emerged from relative obscurity into one of the most well-studied bacterial plant pathogens. While Pierce's disease of grape caused by this pathogen has been recognized as an important disease in warmer regions of the United States for nearly 100 years, the causal pathogen, $X$. fastidiosa has spread throughout much of the world and now also causes serious diseases of citrus, coffee, almond, olive, and other important crop plants. Our knowledge of this pathogen has been driven by the recent substantial research support justified by the economic importance of these diseases.
\end{abstract}

Xylella fastidiosa was considered a rather spatially restricted pathogen, being considered indigenous to North America, and found primarily in warmer climates, where it caused symptoms on only a limited number of primarily woody plant species such as almond where it causes leaf scorch, and peach where it causes phony peach disease (Hopkins and Purcell 2002; Purcell and Hopkins 1996). Several events have elevated the visibility and thus studies of $X$. fastidios $a$ and the diseases that it causes. Beginning in the mid-1980s, $X$. fastidiosa was found to cause citrus variegated chlorosis (CVC), a disease first observed in orange trees in Brazil in 1987 (Hopkins and Purcell 2002; Purcell and Hopkins 1996). By the early 1990s, this disease had spread to $34 \%$ of the 200 million sweet orange trees in the state of São Paulo; by 2005, CVC incidence had increased to $43 \%$ in that region of Brazil, with estimated annual losses of 120 million USD (Bové and Ayres 2007). By the late 1990s, X. fastidiosa was also recognized as a cause of coffee leaf scorch in Brazil and elsewhere (Hopkins and Purcell 2002). While various native sharpshooter vectors such as the blue-green sharpshooter (Graphocephala atropunctata) had long been known to be obligate vectors of $X$. fastidiosa in California, the movement of the glassy-winged sharpshooter (GWSS; Homalodisca vitripennis) into California in the late 1990s was associated with large outbreaks of Pierce's disease (PD) in Southern California, and threatened to change the epidemiology of this disease from one associated with local outbreaks in which the pathogen could exist largely as an endophyte in asymptomatic riparian plants near vineyards, to one in which PD could be widely destructive such as it was in the Temecula

${ }^{\dagger}$ Corresponding author: Steven Lindow; E-mail: icelab@berkeley.edu

(c) 2019 The American Phytopathological Society
Valley of Southern California (Hopkins and Purcell 2002). $X$. fastidiosa has recently been found in Italy where it causes olive quick decline syndrome (Saponari et al. 2017) and is now recognized to have been present in France and Spain for some time and is only now associated with various diseases in these European sites (Sicard et al. 2018).

An analysis of the published literature on diseases caused by $X$. fastidiosa and the pathogen itself reveal a very different temporal dynamic compared with that of several other important bacterial plant pathogens (Fig. 1). Comparison of the amount of published literature on X. fastidiosa, Clavibacter species, and Erwinia amylovora reveal quite different temporal trends. While the number of annual publications (both in peer-reviewed articles as well as in proceedings and abstracts as collected by Web of Science) have generally increased for all three pathogens from the mid-1970s until the current time, the magnitude of this change has dramatically differed between these three pathogens. Relative to the other two pathogens, the number of published studies of $X$. fastidiosa was far less than the other two pathogens until about the year 2000. A majority of studies of E. amylovora or Clavibacter species and the diseases that they cause have, to date, focused on detection methods, descriptions of their occurrence (particularly in the case of E. amylovora as it continues to spread throughout the world), and differential susceptibility of plants to these pathogens, often as a focus of programs for breeding of host resistance. Until relatively recently, a majority of studies of PD and X. fastidiosa also focused on the etiology of the disease and the identity and behavior of insect vectors to better address the epidemiology of the disease. Beginning in about the year 2000, however, substantial new financial resources and advanced molecular techniques came together to enable a wide variety of genetic, physiological, and other studies to be performed. For that reason, the number of reports of $X$. fastidiosa have climbed 
sharply, greatly exceeding that of many other plant pathogens (Fig. 1).

As its name implies, $X$. fastidiosa is a fastidious organism that was not cultured until 1978 (Davis et al. 1978). Not only did its culturing enable demonstration of Kochs postulates, but it greatly facilitated studies of its physiology and made possible various sensitive quantitative detection methods such as PCR and culturing. Forward-looking investments into the sequencing of a CVC strain of $X$. fastidiosa in 2000 made it the first plant-pathogenic bacterium for which a complete genome sequence was available (Simpson et al. 2000), despite the fact that at the time no workable genetic system for this pathogen was available. This genomic information, however, greatly facilitated inferences about its biology. Considerable funding was also dedicated by Brazilian authorities such as the São Paulo Research Foundation-FAPESP to exploit the genome sequences, and substantial work on the basic microbiology of $X$. fastidiosa such as biofilm formation and various physiological processes were conducted. The early presence of the sequence of the CVC and subsequent sequences of PD strains and those infecting other plants made $X$. fastidiosa somewhat of a model organism for which comparative biology with other bacterial species was exploited. Early work also developed various means by which forward genetics could be performed, including knockout vectors, in vitro transposomes, and finally site-directed knockout of genes, and expression of heterologous sequences such as various marker genes greatly facilitated its study.

Unquestionably, the most important element in the rapid ascension of $X$. fastidiosa as a target of investigation was the introduction of substantial research funding. Considerable funding was made available in Brazil from FAPESP because of the considerable economic impact of CVC on the citrus industry; between 1995 and 2018 over \$128 million has been allocated for research infrastructure and personnel for research on this pathogen. As a complement, about 0.7 million USD was made available by Fundecitrus (a nonprofit organization for citrus protection supported by citrus growers and the citrus industry from São Paulo State) with resources from self-imposed assessments on citrus harvests (A. J. Ayres, personal communication). In addition, the expansion of PD in California with the introduction of the GWSS posed an even larger threat to grape, a major agricultural commodity in California. The State of California, the United States federal government, but importantly, also grape growers saw the need for research to develop responses to this growing threat, and substantial research funds were made available. Particularly noteworthy was the establishment of the Pierce's Disease and Glassy-Winged Sharpshooter Research Board, funded by self-imposed assessments on grape harvests and administered by the California Department of Food and Agriculture. Beginning in 2001, over 36 million dollars have been distributed by this program in a competitive grants program that aims to learn more of the nature of the disease with the goal of developing control strategies. The American Vineyard Foundation and other state and local governmental agencies have also provided another $\$ 4$ million to study diseases caused by this pathogen (T. Esser, personal communication). Considerable U.S. federal funds have also been dedicated to studies of $X$. fastidios $a$ and the diseases it causes with over $\$ 16$ million allocated by the U.S. Department of Agriculture (USDA) Cooperative State Research Education and Extension Service/National Institute for Food and Agriculture to support and administer a Research Grant Program. The USDA Agricultural Research Service also has dedicated over $\$ 93$ million to support its staff and infrastructure for research on this topic. These programs have funded many different aspects of the epidemiology of the disease, the nature of interactions of the pathogen with insect vectors and host plants, and vector transmission mechanisms. Considerable effort has also been made to identify natural sources of resistance among grape genotypes. Perhaps most noteworthy however is their support for a variety of fundamental aspects of the nature of the response of plants to the pathogen, the physiology of the pathogen, as well as virulence factors utilized by the pathogen. Without question, it has been such support that has led to the recent voluminous published literature on X. fastidiosa (Fig. 1). Because of the recent emergence of $X$. fastidiosa in Europe, recently two large multi-investigator projects totaling $€ 13.8$ have been funded through the Horizon 2020 program. Such new funding being made available to a new cadre of researchers in Europe will undoubtedly fuel many additional research reports in the future.

My engagement in studies of $X$. fastidiosa is probably typical of many who now are participating in its investigation. I was somewhat knowledgeable of the pathogen, having served on the thesis committees of several students of Professor Alexander Purcell, one of the pioneers in the study of $X$. fastidiosa, as well as having the opportunity to interact with Professor Michael Davis who first cultured this pathogen while he was a student at the University of California-Berkeley. In particular, it has been my pleasure to work closely with my colleague Professor Rodrigo Almeida, himself having trained with Professor Purcell. It had been my impression that the pathogen was difficult to work with (an impression that has not changed with time even after my considerable experiences with it), and that little or no funding had been available to explore this pathosystem. With the outbreak of severe PD in Southern California associated with the introduction of the GWSS, however, the promise of potential research funding and highly informative, interactive research discussion forums sponsored by the University of California and other vested parties prompted my deliberations as to what novel research avenues were possible. Fortunately, the
FIGURE 1

Number of instances in which Xylella fastidiosa or

Pierce's disease (blue line), any Clavibacter species (red line), or Erwinia amylovora or fire blight (black line) appeared in either the title or

keywords of peer-reviewed articles, conference proceedings, or conference abstracts as collected in a given calendar year by Web of Science.

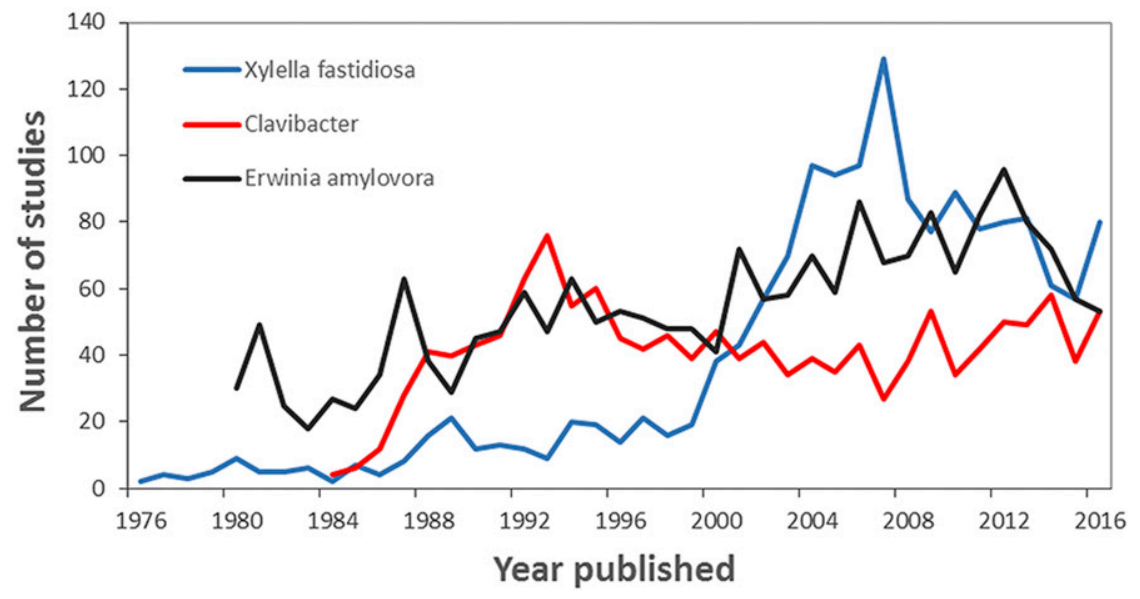

Vol 109, No. 2, 2019 
recently published genome sequence for $X$. fastidiosa had become available, and given my prior interests and experience in working with quorum sensing systems in other bacteria such as Pseudomonas syringae led me to investigate what proved to be the very different, fatty acid-based quorum sensing system in $X$. fastidiosa that is somewhat analogous to that previously described in Xanthomonas campestris pv. campestris. Our work showed that this system coordinated expression of genes in X. fastidiosa in a manner very different from that in Xanthomonas, but in a pattern that proved to be essential for the complicated lifestyle that it has in its two different hosts-unlike that of $X$. campestris (Chatterjee et al. 2008; Lindow et al. 2014). It thus has been the entry of scientists with experience working on other plant pathogens as well as those in the broader fields of microbiology and plant biology, attracted both by the growing body of knowledge of this pathogen, the financial resources to pursue promising areas of research, coupled with their desire to solve an important agricultural problem that has led to amazing progress. Much fundamental knowledge applicable to new and practical methods of disease control have already been accomplished as reviewed elsewhere (Chatterjee et al. 2008; Roper and Lindow 2013; Sicard et al. 2018), and in reports in this special issue of Phytopathology. A gene conferring resistance of grape to X. fastidiosa has been identified (Riaz et al. 2006). Extensive genome sequencing of strains of the pathogen from around the world has provided unparalleled insight into patterns of distribution and evolution of the pathogen (Sicard et al. 2018). Details of the interaction of the pathogen with grape hosts has shown the susceptibility of the pathogen to induced host defenses (Rapicavoli et al. 2018), possibly explaining the mechanism by which biological control can be conferred by strains of $X$. fastidiosa having low virulence (Hopkins 2002). Increased resistance of grape to PD has also been shown to be conferred by expressing in transgenic plants heterologous polygalacturonase inhibiting proteins (Agüero 2005), lytic peptides (Dandekar et al. 2012), and pathogen genes conferring the production of fatty acid signal molecules known as diffusible signal factor (DSF) that suppress virulence in $X$. fastidiosa (Lindow et al. 2014). The effectiveness of production of DSF in transgenic citrus for the control of CVC (Caserta et al. 2017) reinforces the success of such a disease control strategy. These studies have all shown proof of principle of how the interaction between the pathogen and the host can be manipulated to achieve disease control.

Given the detailed insights as to the interactions of $X$. fastidiosa with its plant and insect hosts that have come with the substantial funding that has been made available-some of which has pointed toward attractive and unanticipated strategies for disease controlone could wish that such relatively abundant funding could be made available to address the many other important plant pathogens that continue to impact our crops and native plants. While one would never wish for the occurrence of new devastating diseases such as those caused by $X$. fastidiosa, unfortunately only such emergency situations have typically been shown to stimulate sufficient funding to make substantial advances in our understanding of these pathosystems. The recent flurry of research activity on Candidatus Liberibacter species, the presumed causal agents for Huanglongbing disease of citrus, a disease that has long ravaged other parts of the world but now is an important pathogen present in all citrus growing regions of the United States, as well as important diseases of Solanaceous crop plants (Wang et al. 2017), is another example of how an injection of substantial research funding has led to an acceleration of what we know of this disease. These two examples both would suggest that plant pathology research is underfunded, and that the rate of progress in understanding these diseases and their control are limited by the investments being made for their study. I am optimistic that the investments being made in the study of $X$. fastidiosa will prove to be yet another example of agricultural research that yields far more economic benefit than its cost and will also be a poster child for needed, continuing investments in plant pathology research.

\section{LITERATURE CITED}

Agüero, C. B., Uratsu, S. L., Greve, C., Powell, A. L. T., Labavitch, J. M., Meredith, C. P., and Dandekar, A. M. 2005. Evaluation of tolerance to Pierce's disease and Botrytis in transgenic plants of Vitis vinifera L. expressing the pear PGIP gene. Mol. Plant Pathol. 6:43-51.

Bové, J. M., and Ayres, A. J. 2007. Etiology of three recent diseases of citrus in São Paulo State: Sudden death, variegated chlorosis and huanglongbing. IUBMB Life 59:346-354.

Caserta, R., Souza-Neto, R. R., Takita, M. A., Lindow, S. E., and De Souza, A. A. 2017. Ectopic expression of Xylella fastidiosa rpfF conferring production of diffusible signal factor in transgenic tobacco and citrus alters pathogen behavior and reduces disease severity. Mol. Plant-Microbe Interact. 30:866-875.

Chatterjee, S., Almeida, R. P. P., and Lindow, S. 2008. Living in two worlds: The plant and insect lifestyles of Xylella fastidiosa. Annu. Rev. Phytopathol. 46:243-271.

Dandekar, A. M., Gouran, H., Ibanez, A. M., Uratsu, S. L., Agüero, C. B., McFarland, S., Borhani, Y., Feldstein, P. A., Bruening, G., Nascimento, R., Goulart, L. R., Pardington, P. E., Chaudhary, A., Norvell, M., Civerolo, E., and Gupta, G. 2012. An engineered innate immune defense protects grapevines from Pierce's disease. Proc. Natl. Acad. Sci. USA 109:3721-3725.

Davis, M. J., Purcell, A. H., and Thompson, S. V. 1978. Pierce's disease of grapevines: Isolation of the causal bacterium. Science 199:75-77.

Hopkins, D. L. 2005. Biological control of Pierce's disease in the vineyard with strains of Xylella fastidiosa benign to grapevine. Plant Dis. 89: 1348-1352.

Hopkins, D. L., and Purcell, A. H. 2002. Xylella fastidiosa: Cause of Pierce's disease of grapevine and other emergent diseases. Plant Dis. 86:1056-1066.

Lindow, S., Newman, K., Chatterjee, S., Baccari, C., Lavarone, A. T., and Ionescu, M. 2014. Production of Xylella fastidiosa diffusible signal factor in transgenic grape causes pathogen confusion and reduction in severity of Pierce's disease. Mol. Plant-Microbe Interact. 27:244-254.

Purcell, A. H., and Hopkins, D. L. 1996. Fastidious xylem-limited bacterial pathogens. Annu. Rev. Phytopathol. 34:131-151.

Rapicavoli, J. N., Blanco-Ulate, B., Muszynski, A., Figueroa-Balderas, R., Morales-Cruz, A., Azadi, P., Dobruchowska, J. M., Castro, C., Cantu, D., and Roper, M. C. 2018. Lipopolysaccharide O-antigen delays plant innate immune recognition of Xylella fastidiosa. Nat. Commun. 9:390.

Riaz, S., Krivanek, A. F., Xu, K., and Walker, M. A. 2006. Refined mapping of the Pierce's disease resistance locus, $P d R 1$, and Sex on an extended genetic map of Vitis rupestris $\times$ V. arizonica. Theor. Appl. Genet. 113:1317-1329.

Roper, C., and Lindow, S. E. 2013. Xylella fastidiosa: Insights into the lifestyle of a xylem-limited bacterium. Pages 307-320 in: Virulence Mechanisms of Plant Pathogenic Bacteria. N. Wang, J. Jones, G. Sundin, F. White, S. Hogenhout, C. Roper, L. De La Fuente, and J. H. Hams, eds. American Phytopathological Society, St. Paul, MN.

Saponari, M., Boscia, D., Altamura, G., Loconsole, G., Zicca, S., D’Attoma, G., Morelli, M., Palmisano, F., Saponari, A., Tavano, D., Savino, V. N., Dongiovanni, C., and Martelli, G. P. 2017. Isolation and pathogenicity of Xylella fastidiosa associated to the olive quick decline syndrome in southern Italy. Sci. Rep. 7:17723.

Sicard, A., Zeilinger, A. R., Vanhove, M., Schartel, T. E., Beal, D. J., Daugherty, M. P., and Almeida, R. P. P. 2018. Xylella fastidiosa: Insights into an emerging plant pathogen. Annu. Rev. Phytopathol. 56:181-202.

Simpson, A. J. G., Reinach, F. C., Arruda, P., Abreu, F. A., Acencio, M., et al. 2000. The genome sequence of the plant pathogen Xylella fastidiosa. Nature 406:151-157.

Wang, N., Pierson, E. A., Setubal, J. C., Xu, J., Levy, J. G., Zhang, Y., Li, J., Rangel, L. T., and Martins, J. 2017. The Candidatus Liberibacter-host interface: Insights into pathogenesis mechanisms and disease control. Annu. Rev. Phytopathol. 55:451-482. 